\title{
Glycochenodeoxycholate-Induced Apoptosis Is Not Reduced by Augmenter of Liver Regeneration in the Human Hepatoma Cell Line HuH-7
}

\author{
Gerald Ulrich Denk ${ }^{a}$ Ralf Wimmer ${ }^{a} \quad$ Timo Vennegeerts $^{a} \quad$ Thomas Pusl $^{c}$ \\ Wolfgang Thasler ${ }^{\mathrm{b}}$ Christian Rust $^{\mathrm{a}}$

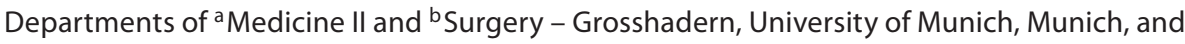 \\ 'First Medical Clinic, Klinikum Augsburg, Augsburg, Germany
}

Dear Sir,

In contrast to other organs, the liver is characterized by an outstanding capacity to regenerate after injuries of diverse etiology. In this context, the protein augmenter of liver regeneration (ALR) is considered to be one of the major players in the process of hepatic regeneration [1] and was found to support liver regeneration in partially hepatectomized rats, in dogs with Eck fistula (portocaval shunt) [2], in rats with thioacetamide-induced liver injury [3], and to decrease hepatic fibrosis in carbon tetrachloride/ethanolinjured rats [4]. Moreover, after partial hepatectomy, an increase of serum but not of liver ALR levels was observed in rats [5], and increased expression of ALR mRNA was observed in cirrhotic human livers [6]. ALR is a homolog of the Erv1 protein from yeast that is essential for $\mathrm{mi}$ tochondrial respiration and cell viability [7], and is a member of the Ervl/ALR protein family of sulfhydryl oxidases [8-10]. This protein family is important for mitochondrial biogenesis, cell cycle, and hepatic and testicular organogenesis [10]. Previous studies in rat hepatocytes and human HepG2 hepatoma cells described a receptor for ALR, that may be important for signal transduction [11]. Furthermore, ALR stimulates the mitogen-activated protein kinase cascade [12], decreases cytochrome $\mathrm{P} 450$, increases nuclear factor$\kappa \mathrm{B}$ activity [13], induces mRNA levels of pivotal enzymes of polyamine biosynthesis and enhances polyamine levels in human hepatocytes [14].

Although the beneficial effects of ALR in liver regeneration are well defined, a protective effect of ALR to reduce liver injury is less clear. Cholestasis is a common cause of liver disease and is characterized by an elevation of hepatic levels of hydrophobic bile acids [15-17]. Hepatocellular apoptosis induced by toxic, hydrophobic bile acids such as glycochenodeoxycholic acid (GCDCA) is a major cause of liver injury in cholestasis [18-20].

In view of ALR's beneficial effects on liver regeneration, we analyzed the role of ALR to reduce liver injury induced by GCDCA in an in vitro model. For this purpose, rat $\mathrm{Na}^{+}$-taurocholate cotransporting polypeptide (Ntcp) was stably transfected into the human hepatoma cell line $\mathrm{HuH}$ 7 with a pcDNA3.1 vector using the
FuGene $^{\circledR}$ transfection reagent (Roche, Mannheim, Germany), similar as described previously [21]. These Ntcp-transfected $\mathrm{HuH}-7$ cells were then transiently transfected with a pcDNA3.1/Myc-HisB ALR construct [22] using TransIT-LT1 reagent (Mirus Bio LLC, Madison, Wisc., USA) for $24 \mathrm{~h}$. This had no effect on cellular bile acid uptake as determined by liquid scintillation counting of Ntcp-HuH-7 cells after incubation with $\left[{ }^{3} \mathrm{H}\right]$ taurocholate (data not shown).

As expected, incubation of NtcpHuH-7 cells with a low micromolar concentration of the hydrophobic bile acid GCDCA $(20 \mu \mathrm{mol} / \mathrm{l})$ for $4 \mathrm{~h}$ led to a 7 -fold increase $(\mathrm{p}<0.01)$ of apoptotic cell death as determined by activities of caspases 3 and 7 with the Apo-ONE homogeneous caspase-3/7 assay (Promega, Madison, Wisc., USA). Despite successful transfection of Ntcp-HuH-7 cells with the hepatopoietic factor ALR as demonstrated by immunoblotting against the Myc-tag (with a monoclonal mouse anti-Myc antibody from Invitrogen, Carlsbad, Calif., USA) and by PCR amplification of ALR mRNA (2,635-fold higher mRNA level after ALR

\section{KARGER}

Fax +41613061234 E-Mail karger@karger.ch www.karger.com
Christian Rust, MD

Department of Medicine II - Grosshadern, University of Munich

Marchioninistrasse 15, DE-81377 Munich (Germany)

Tel. +4989 70950, Fax +498970958864

E-Mail christian.rust@med.uni-muenchen.de 


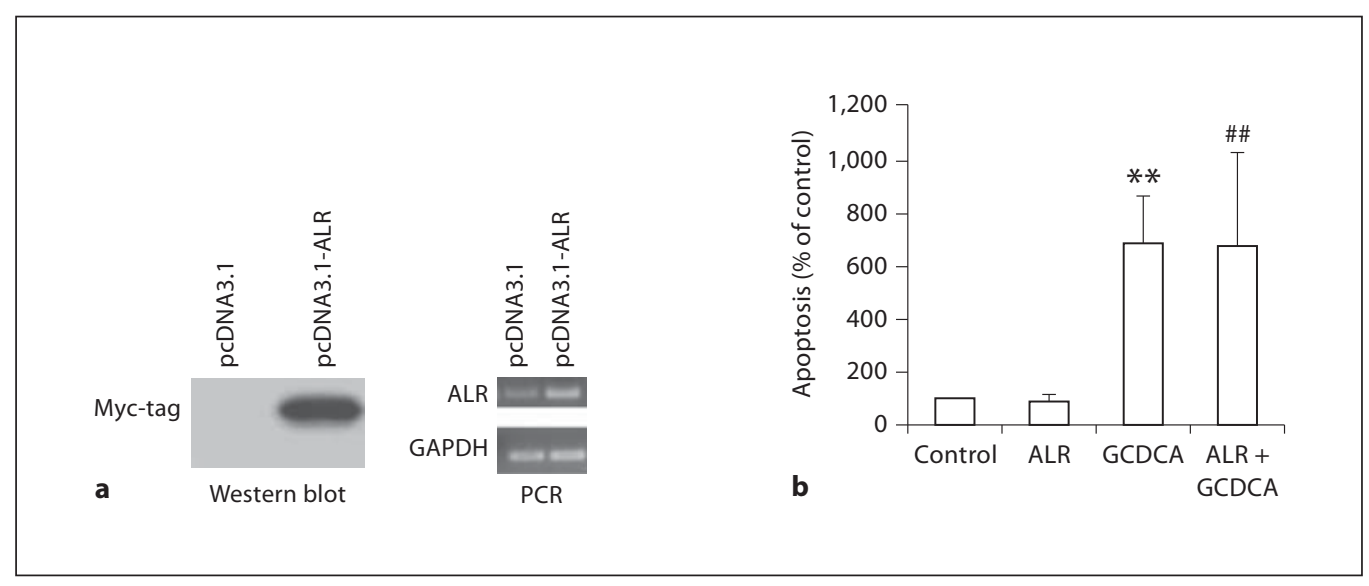

Fig. 1. a A pcDNA3.1/Myc-HisB plasmid containing human ALR was successfully transfected into human hepatoma Ntcp-HuH-7 cells as demonstrated by immunoblotting using an antibody against the Myc-tag of the plasmid and by amplification of ALR mRNA by PCR. b Transfection of ALR does not ameliorate GCDCA-induced apoptosis in Ntcp-HuH-7 cells that were incu- bated with or without the hydrophobic bile acid GCDCA (20 $\mu \mathrm{mol} / \mathrm{l})$. Apoptosis was quantified by determination of the activities of the caspases 3 and 7. Results are expressed as \% of control and means $\pm \mathrm{SD}$ of each 7 independent experiments. ${ }^{* *} \mathrm{p}<$ 0.01 vs. control (no GCDCA); ${ }^{\# \# ~} \mathrm{p}<0.01$ vs. ALR (no GCDCA) (ANOVA with Tukey's post-hoc test). transfection in comparison with controls), apoptotic cell death was not reduced under this condition (fig. 1). In accordance with this observation, cell viability as determined by formazan formation with the WST-1 assay (Roche) and by quantification of LDH activity [23] in the culture medium was not affected by ALR transfection either (data not shown).
Taken together, overexpression of ALR had no beneficial effect on apoptosis induced by low micromolar concentrations of GCDCA, which is one of the predominant bile acids found in cholestatic patients. Thus, our results suggest that ALR might not be beneficial in reducing hepatocellular apoptosis in human cholestatic liver disease.

\section{Acknowledgements}

The pcDNA3.1/Myc-HisB plasmid containing human ALR was a generous gift from Dr. Yan Cao, Beijing Institute of Radiation Medicine (Beijing, China). Dr. Denk is a recipient of a research grant from the Else Kröner-Fresenius-Stiftung.

\section{References}

1 Pawlowski R, Jura J: ALR and liver regeneration. Mol Cell Biochem 2006;288:159169.

-2 Francavilla A, Hagiya M, Porter KA, Polimeno L, Ihara I, Starzl TE: Augmenter of liver regeneration: its place in the universe of hepatic growth factors. Hepatology 1994;20: 747-757.

- 3 Theocharis SE, Margeli AP, Agapitos EV, Mykoniatis MG, Kittas CN, Davaris PS: Effect of hepatic stimulator substance administration on tissue regeneration due to thioacetamide-induced liver injury in rats. Scand J Gastroenterol 1998;33:656-663.

4 Manna Z, Guopei S, Minuk GY: Effects of hepatic stimulator substance, herbal medicine, selenium/vitamin E, and ciprofloxacin on cirrhosis in the rat. Gastroenterology 1996; 110:1150-1155.
5 Gandhi CR, Kuddus R, Subbotin VM, Prelich J, Murase N, Rao AS, Nalesnik MA, Watkins SC, DeLeo A, Trucco M, Starzl TE: A fresh look at augmenter of liver regeneration in rats. Hepatology 1999;29:1435-1445.

-6 Thasler WE, Schlott T, Thelen P, Hellerbrand C, Bataille F, Lichtenauer M, Schlitt HJ, Jauch KW, Weiss TS: Expression of augmenter of liver regeneration in human liver cirrhosis and carcinoma. Histopathology 2005;47:57-66.

7 Lisowsky T: Dual function of a new nuclear gene for oxidative phosphorylation and vegetative growth in yeast. Mol Gen Genet 1992; 232:58-64.

$\checkmark 8$ Lee JE, Hofhaus G, Lisowsky T: Ervlp from Saccharomyces cerevisiae is a FAD-linked sulfhydryl oxidase. FEBS Lett 2000;477:6266.
-9 Lisowsky T, Lee JE, Polimeno L, Francavilla A, Hofhaus G: Mammalian augmenter of liver regeneration protein is a sulfhydryl oxidase. Dig Liver Dis 2001;33:173-180.

10 Gatzidou E, Kouraklis G, Theocharis S: Insights on augmenter of liver regeneration cloning and function. World J Gastroenterol 2006;12:4951-4958.

11 Wang G, Yang X, Zhang Y, Wang Q, Chen H, Wei H, Xing G, Xie L, Hu Z, Zhang C, Fang $\mathrm{D}, \mathrm{Wu} \mathrm{C}, \mathrm{He} \mathrm{F}$ : Identification and characterization of receptor for mammalian hepatopoietin that is homologous to yeast ERV1. J Biol Chem 1999;274:11469-11472.

12 Li Y, Li M, Xing G, Hu Z, Wang Q, Dong C, Wei H, Fan G, Chen J, Yang X, Zhao S, Chen H, Guan K, Wu C, Zhang C, He F: Stimulation of the mitogen-activated protein kinase cascade and tyrosine phosphorylation of the epidermal growth factor receptor by hepatopoietin. J Biol Chem 2000;275:37443-37447. 
-13 Thasler WE, Dayoub R, Muhlbauer M, Hellerbrand C, Singer T, Grabe A, Jauch KW, Schlitt HJ, Weiss TS: Repression of cytochrome $\mathrm{P} 450$ activity in human hepatocytes in vitro by a novel hepatotrophic factor, augmenter of liver regeneration. J Pharmacol Exp Ther 2006;316:822-829.

- 14 Dayoub R, Thasler WE, Bosserhoff AK, Singer T, Jauch KW, Schlitt HJ, Weiss TS: Regulation of polyamine synthesis in human hepatocytes by hepatotrophic factor augmenter of liver regeneration. Biochem Biophys Res Commun 2006;345:181-187.

-15 Greim H, Czygan P, Schaffner F, Popper H: Determination of bile acids in needle biopsies of human liver. Biochem Med 1973;8: 280-286.

16 Greim H, Trülzsch D, Czygan P, Rudick J, Hutterer F, Schaffner F, Popper H: Mechanism of cholestasis. 6. Bile acids in human livers with or without biliary obstruction. Gastroenterology 1972;63:846-850.
Hofmann AF: Cholestatic liver disease: pathophysiology and therapeutic options. Liver 2002;22(suppl 2):14-19.

18 Sokol RJ, Straka MS, Dahl R, Devereaux MW, Yerushalmi B, Gumpricht E, Elkins N, Everson G: Role of oxidant stress in the permeability transition induced in rat hepatic mitochondria by hydrophobic bile acids. Pediatr Res 2001;49:519-531.

19 Sola S, Amaral JD, Aranha MM, Steer CJ, Rodrigues CM: Modulation of hepatocyte apoptosis: cross-talk between bile acids and nuclear steroid receptors. Curr Med Chem 2006;13:3039-3051
20 Rust C, Bauchmuller K, Fickert P, Fuchsbichler A, Beuers U: Phosphatidylinositol 3-kinase-dependent signaling modulates taurochenodeoxycholic acid-induced liver injury and cholestasis in perfused rat livers. Am J Physiol 2005;289:G88-G94.

21 Glasova H, Berghaus TM, Kullak-Ublick GA, Paumgartner G, Beuers U: Tauroursodeoxycholic acid mobilizes $\alpha$-PKC after uptake in human HepG2 hepatoma cells. Eur J Clin Invest 2002;32:437-442.

22 Cao Y, Fu YL, Yu M, Yue PB, Ge CH, Xu WX, Zhan YQ, Li CY, Li W, Wang XH, Wang ZD, Li YH, Yang XM: Human augmenter of liver regeneration is important for hepatoma cell viability and resistance to radiation-induced oxidative stress. Free Radic Biol Med 2009; 47:1057-1066.

23 Bergmeyer HU, Bernt E: Lactate dehydrogenase; in Bergmeyer HU (ed): Methods of Enzymatic Analysis. New York, Academic Press, 1983, vol 3, pp 574-579. 